\title{
Diversification and its Determinants: A Search for an Alternative Income and Agricultural Development in Eastern India
}

\author{
K.M. Singh, Nasim Ahmad*, D.K. Sinha, R.K.P. Singh and R.R. Mishra \\ Department of Agricultural Economics, Dr. Rajendra Prasad Central Agricultural University, \\ Pusa, Samastipur (Bihar)-848 125 \\ *Corresponding author
}

A B S T R A C T

\section{Keywords}

Diversification, Herfindahl index, Eastern India, Poverty alleviation

Article Info

Accepted:

07 January 2018

Available Online:

10 February 2018
Crop diversification is an important strategy for overall development of agriculture of the nation, in general and eastern India, in particular, where abundance of rich natural resources is available. The present investigation was an attempt to know the extent of diversification and identify the influencing factors of diversification in this region. The study is based on secondary data from 2001-02 to 2014-15. Herfindahl index was applied to calculate the diversification index and multiple regression analysis was used to examine the factors affecting diversification. The diversification was found less for the region having dominant traditional system of farming. The major factors such as percentage of HYVs area to GCA, average holding size and per capita income could be identified as determinants of crop diversification in eastern region. Strengthening of crop diversification depends on market and mitigation of production risks through technological support, quality input supply, insurance cover and existence of modern storage-processing centers in the region. Keeping in view the rich natural resources and hidden agricultural development opportunities in this region, government is taking initiatives/steps so as to begin Second Green Revolution right from the region through use of huge resource potential to obtain optimum harvest.

\section{Introduction}

Crop diversification has been a vital issue of discussion among the researchers and policy makers and they have been trying to relate diversification with developmental prospects (Birthal et al., 2007; Swati et al., 2017). The optimal cropping pattern for the country and specifically for eastern India, where agriculture is the mainstay of economy, is a serious challenge to the economist and planners. Some economist suggested that the shifting of area from traditional paddy and wheat cultivation to alternative crops is the solution of the phenomena (Shergill, 2005). Traditionally, diversification was used more in the context of a subsistence type of cultivation wherein cultivators cultivated many crops on their farms. Crop diversification is intended to give a wider choice in the production of variety of crops in a given area so as to expand production related activities on various crops 
and also to lessen risk (Kalaiselvi, 2012). Crop diversification in India is generally viewed as shift from traditionally grown less remunerative crops to more remunerative crops. The crops shift also takes place due to government policies and thrust on some crops over given time, for example, creation of Technology Mission on Oilseeds (TMO) to give impetus on oilseeds production as a national need for the country's requirement for less dependency on imports (CMIE). Market infrastructure development and certain price related supports also induce crop diversification. Often high value crops like, spices also aid in crop diversification.

Crop diversification is essential for agriculture based economy. Conventional experiences of the farmers over years have compelled them to diversify farm activities to fulfill the cash need of their families and also to mitigate the risks like changing climatic conditions, declining water tables, flood and drought conditions and also shrinking net sown area (Sinha et al., 2016). The crop diversification is also getting great attention due to market infrastructure, availability of resources, public intervention (Price and credit policies, research and development) and globalization of agriculture (Kumar et al., 2012 and Singh at al. 2013).

In general, level of diversification is governed by the market forces (Relative price, profitability of crops), advancement of technology (access to inputs and implements), agro-climatic conditions, development of infrastructural facilities like; communication, market and storage facility and institutional factors like government's policy, protection and risk factors (De UK and Chattopadhayay, 2010; Patnayak and Nayak, 2004; Mruthhyunjaya, 1989; Radhakrishnan et al., 1988; Ghosh, 2011).

The eastern region of India comprising the states of Bihar, Jharkhand, Odisha and West
Bengal is one of the most backward regions (32.10\% below poverty line population and maximum number of economically most backward districts (69 out of 150 at national level) of the nation. This region occupies about $21.85 \%$ of geographical area and supports $34 \%$ of the population of the country. The population density is 1.91 fold higher in Eastern states to national average. Agriculture is the mainstay of economy in this region. The net sown area is 29.17 million hectare with cropping intensity of $150 \%$ in the region. The average rainfall varies from 1091 to $2477 \mathrm{~mm}$ with an average of $1526 \mathrm{~mm}$ in the region which is sufficient to grow a variety of crops. However, the irrigated area is the eastern region is about $39 \%$ as against $45 \%$ of the country's average.

About $67 \%$ of the cultivators belonged to marginal group and over $75 \%$ of their earnings are utilized to ensure food security. Eastern India is endowed with natural resources (145.12 BCM annual ground water availability, groundwater draft is only $36 \%$ ). Despite the rich natural resources (fertile land, abundant ground water), the pace of agricultural development is very slow (Ahmad et al., 2017). There is lot of scope to accelerate farmer's income by improving productivity and including high value crops in cropping pattern of the region. Growth in agricultural production and income may be brought about from two angles viz., expansion of land area put to agricultural uses and/or more productive use of existing cultivable land area. However, the first option may not further support on account of population growth and thus, increasing demand for land for nonagricultural uses. Now, the option is to enhance agricultural production which is of major concern and this can be undertaken with the packages like increase in cropping intensity of land, shift in cropping pattern in favour of crops with higher productivity, improvement in cultivation technologies and 
institution change in farming sector. For sustained agricultural growth in the long run, institutional changes are to be followed by improvements in the cultivation practices like adoption of quality seeds, economical irrigation systems, judicious use of fertilizers, appropriate plant protection measures, which may enhance the productivity from a given land resource and further would boost the income of the cultivators. Sustainable use of rich natural resources and hidden agricultural development opportunities would pave the way for Second Green Revolution in the region.

In the present paper, an attempt has been made to analyze the extent of diversification and to identify the factors influencing diversification in the region.

\section{Materials and Methods}

To meet the objectives of the present study, time series data of eastern India consisting the states of Bihar, Jharkhand, Odisha, Assam and West Bengal were collected from various published sources for the period 2001-02 to 2014-15, pertaining to area under different crops groups, population density, rainfall, gross irrigated area, area under HYV crops, fertilizer use $(\mathrm{Kg} / \mathrm{ha})$, average land holding size (ha), and per capita income (000' rupees). The magnitude of diversification can be measured by number of statistical methods which include Index of Maximum Proportions, Simpson Index, Entropy Index, Modified Entropy Index, Composite Entropy Index, Ogive index and Herfindahl-Hirschman Index, etc. Kumar et al., (2012), Benin et al., (2004), Chand (1996) and Pandey and Sharma (1996) have used these indices in their studies. Each of these tools has its own advantages and limitations in terms of data requirement, level of sophistication and ease of computation and interpretation. Further, the results obtained through these methods are more or less similar. In this investigation to find out the extent of diversification, Crop Diversification Index (CDI) was worked out using Herfindahl index (HI). The Herfindahl index is sum of square of the proportion of individual crop groups in a portfolio. With an increase in diversification, a sum of the square of the proportion of crop groups (HI) decreases. This is measure of concentration, alternatively, an inverse measure of diversification since the Herfindahl index decreases with an increase in diversification. The $\mathrm{HI}$ is bound by zero (Complete diversification) to one (complete Specialization).

$$
\text { Herfindhal Index }(H I)=\sum_{i=1}^{n} P_{i}^{2}
$$

Where $\mathrm{P}_{\mathrm{i}}$ is the proportion of the area of crop group

\section{Crop Diversification Index $\quad \mathrm{CDI}=1-\mathrm{HI}$}

Where HI = Herfindahl index

The CDI has the direct relationship with diversification. The zero value of CDI indicates specialization and moving towards one showing increase in level of diversification.

To identify the factors affecting diversification multiple regression analysis was carried out using the time series data from 2001-02 to 2014-15. The crop diversification index (CDI) $(\mathrm{Y})$ was specified as function of the following independent variables.

$$
Y=a+b_{1} X_{1}+b_{2} X_{2}+b_{3} X_{3} \ldots \ldots+b_{n} X_{n}+U
$$

The explanatory variables were as under:

$\mathrm{X}_{1}=$ Population density (per square $\mathrm{Km}$ )

$\mathrm{X}_{2}=$ Annual rainfall $(\mathrm{mm})$

$\mathrm{X}_{3}=$ Percentage of gross irrigated area (GIA)

to gross cropped area (GCA) 
$\mathrm{X}_{4}=$ Percentage of HYV area to gross cropped area (GCA)

$\mathrm{X}_{5}=$ Per capita income (thousand rupees)

$\mathrm{X}_{6}=$ Fertilizer consumption $(\mathrm{Kg} / \mathrm{ha})$

$\mathrm{X}_{7}=$ Average land holding size (ha)

\section{Results and Discussion}

Analysis of cropping pattern of eastern India revealed that the share of cereal crops was observed to be $66.81 \%$ at TE-2004, which decreased to $64.82 \%$ at TE-2007 and further increased to $65.35 \%$ at TE-2015 (Table 1). The rise in proportion of cereals may be due to shifting of area under pulses and oilseeds to the cereal crops. Decline in area under oilseed and pulses might be due to risk of pest and diseases and damage of pulses crops by animals. The share of food grains remained almost constant throughout the study period. The eastern India has higher proportion of the cultivated area under high value crops like vegetables (about 8.87\% TE-2015) as compared to all-India average (5.0\%). The probable reason may be the conducive agroclimatic conditions for cultivation of varieties of off-season vegetables, fruits, flowers and other high value crops in eastern India. Small size and fragmented landholdings, high population density, food insecurity, poverty, underdeveloped rural infrastructures, and frequent occurrence of natural calamities like flood and drought may be the probable causes of almost constant share of food grains to gross cropped area in this region.

\section{Nature and extent of diversification}

The crop diversification indices (CDI) of different states of eastern India and region as a whole are shown in Table 2. A critical examination of the table indicated that diversification indices for eastern India for the period under investigation remained almost stagnant. The result reflected that the cultivators of eastern India were traditional cultivators and were mainly engaged in cultivation of food crops for their food security. Less developed infrastructures and marketing facilities were some of the other bottlenecks. The diversification of crops was found comparatively less in Bihar and Jharkhand with respect to Assam, Odisha and West Bengal. Despite rich natural resources like groundwater and fertile land in Bihar, irrigation facilities were observed rather costly; and lack of proper marketing facilities. Probably because of the other prevailing reasons, cultivators used to hesitate in diversifying their crops due to risk aversion attitude of them. Diversification was observed relatively less in Jharkhand mainly because it is considered as dry hilly state.

\section{Determinants of diversification}

To identify the various factors underlying crop diversification in eastern India, Log-linear regression analysis was carried out.

Diversification index was regressed on several causal factors. To capture the effect of technology adoption, the variables such as percentage of HYV area to gross cropped area, fertilizer use $(\mathrm{kg} / \mathrm{ha})$, percentage of gross irrigated area (GIA) to gross cropped area (GCA) were taken and further to capture the effect of climate, rainfall $(\mathrm{mm})$ data were included in the model. Finally, seven independent variables such as population density per square $\mathrm{Km}\left(\mathrm{X}_{1}\right)$, annual rainfall in $\mathrm{mm}\left(\mathrm{X}_{2}\right)$, percentage of gross irrigated area to gross cropped area $\left(\mathrm{X}_{3}\right)$, percentage of HYV area to gross cropped area $\left(\mathrm{X}_{4}\right)$, per capita income $\left(\mathrm{X}_{5}\right)$, fertilizer consumption $(\mathrm{kg} / \mathrm{ha})$ $\left(\mathrm{X}_{6}\right)$ and average land holding size (ha) $\left(\mathrm{X}_{7}\right)$ are considered for analysis (Table 3 ).

The estimated Coefficient of Determination $\left(\mathrm{R}^{2}\right)$ is 0.9384 , indicating that the variables included in the study explain about 94 per cent variation in dependent variables. The remaining variation in dependent variable (crop diversification) is caused by variables 
which are not included in the model. These variables include soil type, access to market and level of farmers knowledge etc. which are either unquantifiable or unavailability of reliable data for eastern India.

Table.1 Cropping pattern of eastern India

\begin{tabular}{|l|c|c|c|c|}
\hline \multicolumn{1}{|c|}{ Crop Groups } & TE-2004 & TE-2007 & TE-2010 & TE-2015 \\
\hline Cereals & 66.81 & 64.82 & 65.20 & 65.35 \\
\hline Pulses & 8.48 & 8.96 & 8.85 & 8.25 \\
\hline Food grains & 75.29 & 73.78 & 74.05 & 73.60 \\
\hline Oilseeds & 6.01 & 6.37 & 5.76 & 4.63 \\
\hline Fibers & 3.09 & 2.86 & 2.93 & 2.85 \\
\hline Fruits & 2.13 & 2.19 & 2.32 & 2.45 \\
\hline Vegetables & 7.29 & 8.19 & 8.37 & 8.87 \\
\hline Condiments \& spices & 1.19 & 1.27 & 1.39 & 1.40 \\
\hline Total food crops & 88.93 & 88.72 & 88.69 & 87.85 \\
\hline Total non-food crops & 11.08 & 11.28 & 11.31 & 12.15 \\
\hline GCA & 100.00 & 100.00 & 100.00 & 100.00 \\
\hline
\end{tabular}

Table.2 Crop diversification index (CDI) in eastern India during 2001-2014-15

\begin{tabular}{|l|c|c|c|c|c|c|}
\hline Year & Bihar & Jharkhand & Assam & Odisha & West Bengal & Eastern India \\
\hline $\mathbf{2 0 0 1 - 0 2}$ & 0.35 & 0.29 & 0.55 & 0.46 & 0.53 & 0.54 \\
\hline $\mathbf{2 0 0 2 - 0 3}$ & 0.32 & 0.30 & 0.54 & 0.45 & 0.54 & 0.52 \\
\hline $\mathbf{2 0 0 3 - 0 4}$ & 0.35 & 0.35 & 0.55 & 0.46 & 0.54 & 0.54 \\
\hline $\mathbf{2 0 0 4 - 0 5}$ & 0.36 & 0.30 & 0.58 & 0.47 & 0.54 & 0.55 \\
\hline $\mathbf{2 0 0 5 - 0 6}$ & 0.38 & 0.29 & 0.58 & 0.45 & 0.54 & 0.57 \\
\hline $\mathbf{2 0 0 6 - 0 7}$ & 0.34 & 0.27 & 0.62 & 0.45 & 0.56 & 0.57 \\
\hline $\mathbf{2 0 0 7 - 0 8}$ & 0.34 & 0.30 & 0.59 & 0.44 & 0.57 & 0.56 \\
\hline $\mathbf{2 0 0 8 - 0 9}$ & 0.33 & 0.29 & 0.58 & 0.45 & 0.55 & 0.56 \\
\hline $\mathbf{2 0 0 9 - 1 0}$ & 0.38 & 0.32 & 0.58 & 0.38 & 0.57 & 0.54 \\
\hline $\mathbf{2 0 1 0 - 1 1}$ & 0.38 & 0.35 & 0.58 & 0.41 & 0.60 & 0.57 \\
\hline $\mathbf{2 0 1 1 - 1 2}$ & 0.33 & 0.34 & 0.59 & 0.43 & 0.58 & 0.55 \\
\hline $\mathbf{2 0 1 2 - 1 3}$ & 0.35 & 0.36 & 0.59 & 0.42 & 0.58 & 0.56 \\
\hline $\mathbf{2 0 1 3 - 1 4}$ & 0.39 & 0.38 & 0.59 & 0.41 & 0.58 & 0.55 \\
\hline $\mathbf{2 0 1 4 - 1 5}$ & 0.41 & 0.42 & 0.59 & 0.41 & 0.58 & 0.55 \\
\hline
\end{tabular}


Table.3 Estimated regression function for determinant of crop diversification

\begin{tabular}{|c|c|c|c|c|}
\hline Particulars & Coefficients & $\begin{array}{l}\text { Standard } \\
\text { Error }\end{array}$ & t -value & P-value \\
\hline Intercept & 0.226663 & 0.968597 & 0.234 & 0.823 \\
\hline Population density $\left(\mathrm{X}_{1}\right)$ & -0.000801 & 0.000752 & -1.065 & 0.328 \\
\hline Annual rainfall $\left(\mathrm{X}_{2}\right)$ & 0.000013 & 0.000018 & 0.688 & 0.517 \\
\hline \% age of GIA to GCA $\left(\mathrm{X}_{3}\right)$ & 0.001136 & 0.002458 & 0.462 & 0.660 \\
\hline$\%$ age of HYV area to GCA $\left(\mathrm{X}_{4}\right)$ & 0.010166 & 0.004129 & 2.462 & 0.049 \\
\hline Per capita income $\left(\mathrm{X}_{5}\right)$ & -0.001888 & 0.000797 & -2.370 & 0.056 \\
\hline Fertilizer consumption $\left(\mathbf{X}_{\mathbf{6}}\right)$ & 0.000154 & 0.000396 & 0.388 & 0.711 \\
\hline Average land holding size $\quad\left(\mathrm{X}_{7}\right)$ & -0.895628 & 0.604707 & -1.481 & 0.109 \\
\hline $\mathbf{R}^{2}$ & 0.9716 & & & \\
\hline Adjusted $\mathbf{R}^{2}$ & 0.9384 & & & \\
\hline
\end{tabular}

Spread of HYV seed emerged as positive and statistically significant variable. Adoption of HYV seed is one of the indicators of agricultural development, hence it may be said that the concerted effort is required for development of farm sector which may facilitate more diversification in eastern India. The estimated coefficients of rainfall; irrigated area and fertilizer consumption are positive but not statistically significant. Rainfall in eastern India is high hence variation in rainfall is unlikely to affect the level of diversification. Irrigation is not found as significant variable for diversification because rain fed areas have benefited more as a result of agricultural diversification in favour of high value crops by substituting coarse cereals (Joshi et al., 2003).

Use of chemical fertilizers had no significant relationship to diversification level because farmers did not have easy access to chemical fertilizers in almost unorganized input output market of eastern India. Bittinger (2010) while examining the crop diversification and technology adoption in Ethiopia observed that the intensity of chemical fertilizer adoption decreases and levels of specialization increase as farmers become more isolated from markets.
Pellegrin and Pellegrin (2014) while studying crop diversification in eight developing countries including India observed a positive correlation between the number of crops cultivated and household income on the farm. In the present analysis also, coefficients of both variables (average size of land holdings and per capita income) are negative but statistically significant. Average size of land holdings and per capita income has positive relationship because per capita income of large land holders is higher than small land holders in Bihar (ICAR- RCER, 2015). It indicates that the increase in land size holdings and per capita income are likely to increase the crop diversification in the eastern region. Small land holders may not be able to spare land for cultivation of crops other than staple food due to their consumption consideration. Besides, their per capita income is low and do not have surplus liquid fund to make investment in cultivation of high value crops. Population density exerted negative effect on diversification in eastern India, however, the coefficient was not found significant. Moreover, higher population density means lower per capita land and farmers became more conscious to their consumption need and hesitate to shift their food grain area to high value crops. 
From the foregoing discussion it may be summarized that the very less diversification was observed in the eastern India during the period of investigation. Cropping pattern was found to be almost stagnant in all the triennia under the study. Percentage of HYVs area to GCA, average holding size and per capita income could be identified as determinants of crop diversification in eastern region. Adoption of HYV seed is one of the indicators of agricultural development, hence it may be said that the concerted effort is required for development of farm sector which may facilitate more diversification in eastern India. It may be further concluded that increases in land holding sizes and per capita income may accelerate the crop diversification in the eastern region as small land holders may not be able to spare land for cultivation of crops other than staple food due to their consumption needs. Besides, their per capita income is low and do not have surplus liquid fund to make investment in cultivation of high value crops.

Policy implication of the study may be stated that creation of basic infrastructures (assured and cheaper source of irrigation, good road connectivity) along with processing and value addition of agricultural commodities are required to be developed to push the pace of diversification with a view to raise the income of farming community, which will certainly pave the ways for second green revolution with optimal use of rich natural resources available in the eastern India.

\section{References}

Ahmad Nasim, Sinha, D.K. Singh, K.M. and Kumar Amaledu. 2017. Determinants of Crop Diversification in Bihar Agriculture-An Economic Analysis. Environment \& Ecology 35 (4E): 36833687

Benin, S., Smale, M., Pender, J.,
Gebremedhin, B. and Ehui, S. (2004). The economic determinants of cereal crop diversity on farm in Ethiopian highlands. Agricultural Economics, 3, 197-208.

Bittinger, A.K. 2010. Crop diversification and technology adoption: The role of market isolation in ETHIOPIA, unpublished thesis, Montana State University, Bozeman, Montana

Chand, Ramesh. 1996. Diversification through High Value Crops in Western Himalayan Region: Evidence from Himachal Pradesh. Indian Journal of Agricultural Economics, Vol.41 No.4 pp.652-663.

De UK, Chattapadhyay M (2010). Crop diversification by poor peasants and role of infrastructure: Evidence from West Bengal. J Develop and Agric Econ 2: 340-350. dx.doi.org/10.21921/jas.v3i4. 6709

Ghosh, Bidyut Kumar. 2011. Essence of crop diversification: A study of West Bengal Agriculture Asian Journal of Agricultural Research, 5(1): 28-44.

Shergill, H.S. 2005. Wheat and Paddy cultivation and question of optimal cropping pattern for Punjab. Journal of Punjab Studies pp. 239-250.

Kalaiselvi K. (2012). Pattern of crop diversification in Indian Scenario.Annals of Biological Research 3(4): 1914-1918.

Kumar, Anjani, Pramod Kumar and Alakh N. Sharma. 2012. Crop diversification in eastern India: Status and determinants. Indian Journal of Agricultural Economics, 67(4): 600-616.

Lorenzo Pellegrin and Lorenzo Pellegrin (2014) Crop diversification, dietary diversity and agricultural income: empirical evidence from eight developing countries, Canadian Journal of Development Studies, Vol. 35, Issue. 2.

Mruthhyunjaya P., 1989. Crop economics and cropping pattern changes. Economic and Political Weekly 24: A-159. 
P. K. Joshi, Ashok Gulati, Pratap S. Birthal and Laxmi Tewari. 2003. Agricultural Diversification in South Asia: Patterns, Detrminants and policy implication, MSSD Discussion paper No. 57, International Food Policy Research Institute, Washington, D.C., USA.

Pandey, V.K. and Sharma, K.C. 1996. Crop diversification and self-sufficiency in food grains. Indian Journal of Agricultural Economics, Vol.51 No.4 pp.644-651.

Pattanayak M, Nayak, B. 2004. Performance of agriculture in the changing structure of Orissa economy: Issues revisited, 40th Ann Conf of Ind. Econ Soc, Bangalore, India

Radhakrishnan V, Thomas E. K, Thomas KJ. 1988. Performance of rice crop in Kerala. In: Oommen MA (ed.), Kerala's
Development Experience, Institute of Social Sciences.

Singh, Jaspal, Yadav H. S. and Singh Nirmal. 2013. Crop diversification in Punjab agriculture: A temporal analysis. Journal of Environmental Science, Computer Science and Engineering and Technology Vo. 2 No. 2, 200-205.

Sinha D. K., Ahmad Nasim, Singh K. M. 2016. Shrinking net sown area: An analysis of changing land use pattern in Bihar. Journal of Agrisearch 3(4):238243. DOI: 10.21921/jas.v3i4.6709.

Swati Goswami, Harshika Choudhary and Asha Bisht. 2017. Factors influencing crop diversification as Tool to two fold farmers' earnings in Uttarakhand. Indian Journal of Economics and Development, Vol. 13, No.2a, 228-233.

\section{How to cite this article:}

Singh, K.M., Nasim Ahmad, D.K. Sinha, R.K.P. Singh and Mishra, R.R. 2018. Diversification and its Determinants: A Search for an Alternative Income and Agricultural Development in Eastern India. Int.J.Curr.Microbiol.App.Sci. 7(02): 695-702. doi: https://doi.org/10.20546/ijcmas.2018.702.087 